\title{
Reflections of design-based research approach on learning experience of visual programming course
}

\author{
Hacer Özyurt ${ }^{1}$ and Özcan Özyurt ${ }^{2}$ \\ ${ }^{1}$ Karadeniz Technical University, Of Technology Faculty, Turkey (ORCID: 0000-0001-8621-2335) \\ ${ }^{2}$ Karadeniz Technical University, Of Technology Faculty, Turkey (ORCID: 0000-0002-0047-6813)
}

\begin{abstract}
This study aims to examine the effects of Visual Programming course conducting in accordance with design-based research on students' learning experiences. The study was conducted in the fall semester in 2017-2018 at Software Engineering Department in Technology Faculty of a university in the north of Turkey. The sample of the study consists of 12 students taking the course. In this study based on a twostage research method, the course was taught in accordance with design-based research for 14 weeks. Then the implications of teaching the course in that way for students' visual programming learning experiences are analyzed with the specific case study. At the end of the study, the participants of the study were interviewed through a semi-structured interview form. The qualitative data obtained from the participants are subjected to content analysis. It is seen that students' views can be grouped under five main themes. The results of the study show that the course process which is maintained in accordance with the design-based research method has important contributions for students learning experiences. It is concluded that the views of the students are generally positive but it can be said that there are also negative views about the process even if in limited numbers.
\end{abstract}

Keywords: Design-based research; Visual programming; Engineering education; Students' views

Article History: Submitted 2 September 2019; Revised 28 December 2019; Published online 9 January 2020

\section{Introduction}

In the recent years, it is seen that besides the traditional research methods, design-based research method, whose name has been heard more frequently in recent years, has started to be used. It can be said that the studies focused on the design or development of a product or service are gathered under the framework of design-based research (Kuzu, Çankaya \& Misırl1, 2011). Design-based research is generally defined as a systematic and flexible research conducted in a real environment in which cyclical analysis, design, development and implementation processes are carried out together with researchers and participants and are conducted in order to improve educational practices (Brown, 1992; Wang \& Hannafin, 2005, Yıldırım, 2014). Collins, Joseph and Bielaczyc (2004) describe design-based research as focusing on design and increasing educational development by evaluating design elements. A circular structure is established in design-based research. In these researches, researchers systematically design and implement some interventions.

\footnotetext{
Address of Corresponding Author

Özcan Özyurt, Karadeniz Technical University, Of Technology Faculty, 61830 Of/Trabzon, Turkey.
}

$\square$ oozyurt@ktu.edu.tr

How to cite: Ozyurt, H., \& Özyurt, H. (2020). Reflections of design-based research approach on learning experience of visual programming course. Journal of Pedagogical Research, 4(1), 12-21. 
According to the results of the application, the design is reviewed and reapplied. This cycle is continued until it is concluded that the application has matured sufficiently (Kuzu et al., 2011; McKenney \& Reeves, 2013).

The main feature of design-based research is that this research method is used in the production of innovation. This innovation can be an educational application, a theory or a learning environment (Baltac1, Yıldız, Kıymaz, \& Aytekin, 2016; Çankaya, 2013). As a matter of fact, it is possible to mention the studies emphasizing that design-based research is appropriate in the studies aimed at developing a product such as e-learning environment design (Anderson \& Shattuck, 2012; Kuzu et al., 2011; Revees, 2000; Yıldırım, 2014). In this type of research, instead of looking at the effect of two different applications on academic achievement, as in experimental research, it focuses on the creation of a new environment or product and how to evaluate and revise this process (Amiel \& Reeves, 2008; Baltac1 et al., 2016; Çakır, 2013; Kuzu et al., 2011). Design-based research can generally be considered as studies where design-applicationdevelopment and evaluation stages take place and this process is thoroughly reported (Reeves, 2000). From this perspective, it can be said that design-based research is philosophically based on basic engineering processes (Aşık \& Yılmaz, 2017; Ercan \& Şahin, 2015). As a matter of fact, designbased researches are usually carried out to solve a problem and require learning phenomena to be shaped over time through similar processes in engineering discipline (Aşık \& Yılmaz, 2017; Lesh \& Sriraman, 2005; McKenney \& Reeves, 2013; Özyurt \& Özyurt, 2017a). Ultimately, it can be said that the goal of design-based research is to reveal educational theories, designs and practices that are optimized in terms of effectiveness, efficiency and applicability (Aşık \& Yılmaz, 2017).

It is possible to mention the studies that emphasize the lack of design-based researches in educational studies and the new usage of them (Aşık \& Yılmaz, 2017; Baltac1 et al., 2016; Collins et al., 2004; Kuzu et al., 2011). The situation in our country is not very different. As a matter of fact, it can be said that design-based researches aiming to elaborate the process rather than focusing only on academic success have started to become widespread in different areas in recent years (Baltac1 et al., 2016; Coşkunserçe \& Erişti, 2017; Dönmez, Yaman, Şahin, \& Yurdakul, 2016; Ercan \& Şahin, 2015; Kuzu, Cavkaytar, Çankaya, \& Öncül, 2013; Yaman, Dönmez, Avc1, \& Yurdakul, 2016; Yıldırım, 2014). Although there is a general deficiency in this area, it is also important to carry out studies in these fields when the usability of such research in engineering education and especially in software engineering education is considered. In fact, in the context of software engineering education, design-based research can be used effectively especially in project-based application development processes (Özyurt \& Özyurt, 2017a). The process steps, called the software lifecycle, used to reveal a software product/project are similar to the cyclical structure of design-based research. In this context, design-based research can be used to provide a healthy and detailed process. In terms of engineering education, this is of great importance. As a matter of fact, among the main objectives of engineering education is to educate students in a professional manner such as project process management (Jollands, Jolly, \& Molyneaux, 2012; Zhou, 2012). In addition, Mills and Treagust (2003) talk about the necessity of engineering education to provide students with the knowledge and skills related to design processes. In this respect, the necessity and importance of conducting different studies in the context of design-based research in general for engineering education and in particular for software engineering education is evident. In this context, it is aimed to carry out the visual programming course which is the software engineering department course in accordance with the design based research and to determine the reflections of this process on the students' visual programming learning experiences. Accordingly, the research question of the study is as follows:

What are the reflections of the visual programming course conducted in accordance with the design-based research on students' learning experiences? 


\section{Method}

In this section, information about the research model, participants, application process, data collection tools and data analysis are given.

\subsection{Research Model}

The research model can be considered in two stages. The first stage can be considered as designing and developing software products by conducting the course in accordance with the design-based research. The first stage points to design-based research. The second stage is to find out the reflections from the students' visual programming learning experiences through special case studies. The second stage points to a descriptive study based on the qualitative research approach. In this direction, the interview technique was used to determine the students' views about the learning experience related to this process. In this study, design-based research, which is the first stage, was conducted in the course of application of the course, and in the evaluation stage, the reflection of the application to the student experience was emphasized only as a case study.

\subsection{Participants}

The study group of the research consists of 12 students taking the Visual Programming course one of the elective courses of the Software Engineering Department in Technology Faculty of an university in Turkey. Students taking this course were included in the study in accordance with purposeful sample selection order to answer the research question. The study was conducted in the fall semester in 2017-2018.

\subsection{Process}

The study was conducted in Visual Programming course for a period of 14 weeks. Visual Programming course is the third year elective course of software engineering department and the content of the course consists of software development in a visual programming environment. In this course, development of $C$ \# language is done on Microsoft Visual Studio platform as a visual programming environment. Within the scope of the course, Windows form applications are developed and it is aimed to provide the students with application development skills in this environment. Students taking this course have general programming skills. This course focuses on the development of applications related to visual programming and finally a project. During the course of the course, students were thoroughly informed about design-based research in the first week of the semester. The students formed groups in pairs and decided on the projects to be developed. Students are coded as $S t d 1, S t d 2, \ldots, S t d 12$. Table 1 presents the groups, names and aims of the students' projects.

In the next two weeks, the students created plans for their projects and provided their final status for the software development processes such as tools, software development methodologies and models, software requirements, management and business calendar. The course is planned to be two hours per week in the computer lab and in the form of extracurricular work. During the 10week implementation period, students continued to develop their projects. The students who developed their applications during the extracurricular process were subjected to design evaluations by presenting their projects weekly during the course hours. In other words, the other students who took the course examined these designs separately for each group, criticized them and held brainstorming sessions to reach the final form of the designs. In these sessions, the problems in the designs were discussed and it was aimed to evaluate the possible solutions and apply them to the design and to reflect the usability of the developed product. In this context, the changes in the design around the students' discussions were decided and recorded by the related group members. In this respect, each group continued to develop applications by taking notes about these changes/corrections from these opinions/suggestions/ideas. Briefly, the study process was carried out in accordance with the cyclical structure of the design-based research and the final state of the products was revealed. Last week, students were interviewed. 
Table 1.

Groups, project names, objectives and contents

\begin{tabular}{lll}
\hline Groups & Project name & Aim of the Project \\
\hline Std1-Std2 & Duty monitoring software & $\begin{array}{l}\text { The aim of the project is to develop an application } \\
\text { software that will enable the control of the duty } \\
\text { operations with workplaces, institutions and } \\
\text { organizations. }\end{array}$
\end{tabular}

Std3-Std4 Golden honeycomb contest The aim of the project is to carry out the golden game honeycomb contest game which is one of the current competitions in computer environment and to develop the game which will enable the player to play this game according to the rules.

Std5-Std6 NaberChat application The aim of the project is to develop a communication/chat tool like the widely used messaging tools in the local network.

Std-Std8 Dentist patient monitoring The aim of the project is to develop a desktop software software

for the monitoring of dental patients.

Std9-Std10 Painting tool application The aim of the project is to develop a general purpose paint tool like Paint.

Std11-Std12 Task monitoring software The aim of the project is to develop a desktop automation software in order to monitor the tasks assigned to the personnel by the managers and supervisors in an organization or organization.

\subsection{Data Collection Tools}

Project monitoring form and semi-structured interview form were used as data collection tools. The project monitoring form was kept separately for each group. The purpose of this form is to take notes and monitoring of discussions on projects and design improvements. The semistructured interview form aimed to collect data to determine the reflections of the students' learning experiences related to this process. The interview form was developed by the researchers and finalized after being checked by a linguist. In the form of the questions in the interview form, it was taken care that the students were able to present their perspectives and experiences related to the process from different perspectives. In addition, the questions in the interview form were clearly and clearly understood and did not lead to different meanings. At the end of the application, data was collected from the students individually through the interview form. In this process, the identity of the students was hidden and thus, it was prevented to know who was giving which answers. The interview form includes the following questions:

What do you think about the impact of this process on your software development and programming experience?

What do you think about the impact of this process on your professional development?

What do you think about whether this process affects your study habits?

What do you think about the impact of this process on your problem-solving skills?

What were the positive aspects of this process for you?

$>$ What were the negative aspects of this process for you?

$>$ Do you have any other thoughts you would like to add? 


\subsection{Data Analysis}

At the end of the research, qualitative data obtained from the participants were analyzed through content analysis. In order to prevent misunderstanding of the qualitative data obtained from the students through writing, the participant confirmation was applied. In this way, it was tested whether the participants' answers to each question in the interview form were correctly understood by the researchers, and if there were misunderstandings, the necessary notes were dropped by the students. At this stage, investigator triangulation was applied to increase the validity and reliability of data analysis. In this direction, the interview forms were read meticulously by the two researchers and the codes were prepared. Based on these codes, themes and sub-themes have been shaped. These analyzes carried out by two researchers were reviewed with the gathering of the researchers. Thus, a common agreement was reached on the small differences between the researchers and the final themes were obtained. The themes and subthemes obtained at the end of this analysis process are presented to the readers in the findings section together with frequency information. In order to confirm the content analysis, students' opinions about each theme were given directly without commenting. In addition, the method and reason for the transferability of the sample have been presented and the whole process of the research has been clearly described.

\section{Results}

In this section, the findings of the analysis of the interviews with the students in order to determine the effects of conducting Visual Programming course in accordance with the designbased research process on the students' learning experiences are presented. Students' views on this process are grouped under five main themes. These main themes are named as "research-based learning", "study habits", "professional experience", "self-confidence" and "problem solving". The theme, sub-theme and frequency information obtained as a result of content analysis are given in Table 2.

Table 2.

Information on main theme, sub-theme and frequencies obtained by content analysis

\begin{tabular}{llc}
\hline Main theme & Sub-theme $(+/-)$ & Frequency \\
\hline Research-based learning & Learning to research $(+)$ & 4 \\
& Time spent researching $(-)$ & 4 \\
& Difficulty of research-based learning $(-)$ & 2 \\
Study habits & Planned study $(+)$ & 8 \\
& Cooperation $(+)$ & 4 \\
Professional experience & Preparing for business life $(+)$ & 6 \\
& Contribution to software development processes & 4 \\
Self-confidence $(+)$ & $(+)$ & 3 \\
Problem solving $(+)$ & & 7 \\
\hline
\end{tabular}

In Table 2, the (+) symbol is used in front of the themes and sub-themes in which positive views are presented, and (-) symbol in front of the themes in which negative views are presented. In addition, frequency information showing the frequency of repetition of each theme/sub-theme is included in the table. At the end of the analyzes, it is seen that the themes called "Self-confidence" 
and "Problem solving", which express positive opinions, are independent from other themes and do not contain any sub-themes.

The themes of "learning to research", "time spent researching" and "difficulty of research-based learning", which were obtained by analyzing students' views, were generally related to researchbased learning. In this context, it was decided that the relevant themes should be gathered under the main theme of "Research-based learning" and the main theme was named with this name. The students expressed their views on the process carried out in accordance with the design-based research and expressed their experience in research-based learning and research in this process. Some of the students $(n=4)$ stated that this process increased their experience in research. In this context, the views of Std4 and Std10 regarding the sub-theme of "learning to research" are as follows;

Std4: ...It was useful to learn by investigating many unfamiliar topics and how to correct them by seeing our mistakes...

Std10: ... Increased my ability to research...

Some of the students $(n=4)$ expressed their negative opinions about this process and suffered from the time devoted to the research. As a matter of fact, the statement of Std4 regarding the "time spent researching" was as follows;

Std4: ... This study took me too much time...

Very few of the students $(n=2)$ stated that they had difficulty in doing research especially in this process. Std9's view of the sub-theme of the "difficulty of research-based learning" is as follows;

Std9: ... I made a lot of effort to master the programming language and eliminate the problems in the process. While making the project, I made an effort to research and learn. This is hard for me...

It was seen that the themes which were obtained from the students 'views and called as "planned study" and "cooperation" were positive situations on the students' study habits. Therefore, it was concluded that the relevant themes should be gathered under the main theme of "study habits". The majority of the students $(n=8)$ stated that this process gained the habit of planned study. The views of Std3 and Std8 regarding "planned study" sub-theme are as follows;

Std3: ...After this work, I started to make all my study planned. I set myself daily, weekly and monthly goals...

Std8: ...I usually leave unplanned study to the last day, I had to work with this study planned. Otherwise, things wouldn't work out. It was useful in this respect...

Some of the students $(n=4)$ think that study with together in this process provides important gains. In this context, Std6 and Std11's view on the "cooperation" sub-theme is as follows;

Std6: ... I usually prefer to study alone. I've seen things go better with teamwork...

Std11: ...Being in the form of group study helped my team work. Together with my group friend, we became a good team and overcame the problems we faced during the process of developing and improving the project...

It was seen that the themes, which were obtained from the students 'views, called as "preparing for business life" and "contribution to software development processes", were related to the students' experience in the software engineering profession and their expectations about the business life. Therefore, it was concluded that the relevant themes should be gathered under the main theme of professional experience. Half of the students $(n=6)$ emphasized the contribution of this process to preparing themselves for professional life. As a matter of fact, the views of Std1 and Std10 regarding the sub-theme of "preparing for business life" are as follows; 
Std1: ... I have some ideas about what kind of steps I should follow in the projects I will take part in my professional life. I think I'm better prepared for business...

Std10: ... In this study, we have seen to a large extent the situations we may encounter in the real business world. It was useful in this respect...

Some of the students $(n=4)$ expressed their views on the project development processes and methods. In this context, Std3's view on the sub-theme of "contribution to software development processes" is as follows;

Std3: ... I have come a long way to better observe software development processes and to learn what to consider in each of these processes...

A small number of students $(=3)$ emphasize that this process increases their self-confidence. This view was called "self-confidence". It was found that this theme did not have a direct relationship with other existing themes and appeared independently. This theme was left alone as it was understood that it did not have any sub-themes. Std7's view on the main theme of "selfconfidence" is as follows;

Std7: ... I think that I can develop projects on my own or I have gained this trust...

Finally, it was seen that more than half of the students $(n=7)$ were able to overcome the problems they faced in this process and find solutions to the problems, suggesting that they contribute positively to problem solving skills. These views were named as "problem solving". This theme has the characteristics of the theme of self-confidence. Problem solving is left as the main theme. The views of Std2, Std3, Std6 and Std8 regarding the main "problem solving" theme are as follows;

Std2: ...I had to write many different database queries that I didn't write before. I would say that this study certainly improved my problem-solving ability...

Std3: ... I have learned to overcome the problems I face...

Std6: ...Confronted with new problems and trying to find solutions to them helped me to improve...

Std8: ... Of course, people have problems writing code. My experiences in solving these problems have improved my problem-solving skills...

\section{Discussion and Conclusion}

In this study, it is aimed to determine the reflections of conducting Visual Programming course in accordance with design based research on students' learning experiences. The results of the study revealed the views of students, the majority of whom were positive about this process. In this study, where positive opinions were revealed in terms of teaching research-based learning, making positive contributions on study habits and professional experience, increasing selfconfidence and developing problem solving skills, negative opinions emerged, though limited in number, about the time devoted to research and the difficulty of research-based learning.

When the reflections of the design-based research process on the learning experience of the students are considered, it is obvious that they make significant contributions to the students. In particular, the fact that this process contributes to students' research-based learning and study habits and professional development highlights the usefulness of this method in different application courses. The place of research-based learning in engineering education is very important. In fact, many studies in the literature emphasize the importance and necessity of research-based learning in engineering education (Froyd, Wankat, \& Smith, 2012; McNeill, Douglas, Koro-Ljungberg, Therriault, \& Krause, 2016; Özyurt \& Özyurt, 2017b). McNeill et al. (2016) stated that individuals who have engineering profession will be in a continuous research 
and learning process in order to cope with the problems they will face in their professional lives. In this respect, it can be said that the learning result obtained in the study serves engineering education in this respect. In the context of study habits, it is concluded that this process positively affects students' planned and collaborative study habits.

The fact that the design-based research process contributes positively to the professional life of the students can also be considered as an expected result. Indeed, in this regard, Edelson (2001) emphasizes that design-based research plays an important role in improving design as well as helping researchers in the process to better understand events. This judgment also makes the contribution of the research results to the students' professional development more meaningful. As a matter of fact, among the expectations from engineering education in the field literature, students gain knowledge and skills related to design processes and prepare them for the business world (Litzinger, Lattuca, Hadgraft, \& Newstetter, 2011; Mills \& Treagust, 2003; Zhou, 2012). In addition, one of the objectives of engineering education is to educate students in professional areas such as project process management (Jollands et al., 2012; Zhou, 2012). In addition, Mills and Treagust (2003) talk about the necessity of engineering education to provide students with the knowledge and skills related to design processes. From this point of view, the results of this study directly meet the necessity of engineering education to prepare students for business life and make important contributions to them in this direction.

Other positive results of this process were obtained by providing students self-confidence and developing problem-solving skills. These skills are accepted not only in engineering education but also in almost all of today's individuals (Duran, 2015). In terms of engineering education, it is possible to say that these two elements are important. As a matter of fact, Chua, Yang and Leo (2014) stated that the primary focus of engineering education is the problem solving skills of the students and the development of these skills. Students' coping with their problems and increasing their experiences will increase their self-confidence and professional experience (Jollands et al., 2012; Palmer \& Hall, 2011; Zhou, 2012). From this point of view, considering the results of this study, it becomes possible to say that the design-based research process directly serves the outcomes of engineering education.

Although positive results have been achieved in the study, it is important that negative opinions, even if limited, are put forward in terms of conducting and evaluating such studies. The students' negative opinions about the design-based research process are related to the research. As a matter of fact, few of the students stated that the research took a lot of time and it was difficult to learn with this method. It is known in the literature that there are negative perspectives towards research (Özyurt \& Özyurt, 2017b; Windschitl, 2003). In addition, Levy and Petrulis (2012) stated the difficulty of doing research in research-based learning activities. From this point of view, the results of the study are in line with the results of the studies in this field.

\section{Recommendations}

This study is limited to visual programming course. The design-based research method can be used effectively in engineering education, in particular in software engineering education, especially in courses involving design and application processes. As a matter of fact, such applications can be expected to make significant contributions to the professional development and personal characteristics of students in the realization of software life cycle and design processes. The fact that the results of the study, which can be evaluated as negative, is based on research necessitates further efforts in this field. In this context, more research-based activities can be included in the courses.

\section{Acknowledgement}

This article is an extended version of the abstract paper that oral presented at the 12th International Computer \& Instructional Technologies Symposium held on May 2-4, 2018 in Izmir, Türkiye. 


\section{References}

Amiel, T., \& Reeves, T. C. (2008). Design-based research and educational technology: Rethinking technology and the research agenda. Educational Technology \& Society, 11(4), 29-40.

Anderson, T., \& Shattuck, J. (2012). Design-based research a decade of progress in education research?. Educational Researcher, 41(1), 16-25.

Aşık, G., \& Yılmaz, Z. (2017). Matematik eğitimi çalışmalarında tasarım tabanlı araştırma ve öğretim deneyi yöntemleri: Farklar ve benzerlikler. Eğitimde Kuram ve Uygulama, 13(2), 343-367.

Baltacı, S., Yıldız, A., Kıymaz, Y., \& Aytekin, C. (2016). Reflections from a design based research preparing geogebra supported activities towards gifted students. Mehmet Akif Ersoy Üniversitesi Eğitim Fakültesi Dergisi, 39, 70-90.

Brown, A.L. (1992). Design experiments: Theoretical and methodological challenges in creating complex interventions in classroom settings. Journal of the Learning Sciences, 2 (2), 141-178.

Chua, K. J., Yang, W. M., \& Leo, H. L. (2014). Enhanced and conventional project-based learning in an engineering design module. International Journal of Technology and Design Education, 24(4), 437-458.

Collins, A., Joseph, D., \& Bielaczyc, K. (2004). Design research: Theoretical and methodological issues. Journal of the Learning Sciences, 13(1), 15-42.

Coşkunserçe, O., \& Erişti, S. D. B. (2017). Uluslararası öğrencilerin kültürel uyum sürecine yönelik tasarım tabanlı araştırma yaklaşımına dayalı çevrimiçi oryantasyon uygulamasının geliştirilmesi. Eğitim Teknolojisi Kuram ve Uygulama, 7(1), 83-104.

Çakır, Ö. (2013). Tasarim tabanli araştirma. In K. Çağıltay ve Y. Göktaş (Eds.). Öğretim teknolojilerinin temelleri: Teoriler, araştırmalar, eğilimler. (pp. 365-378). Ankara: Pegem.

Çankaya, S. (2013). Development and evaluation of skill teaching software for parents of individuals with intellectual disability to teach self-care and domestic skills. (Unpublished Doctoral Dissertation). Anadolu University, Turkey.

Dönmez, O., Yaman, F., Şahin, Y. L., \& Yurdakul, I. K. (2016). Developing mobile applications for hearingimpaired: wheel of fortune. Educational Technology Theory and Practice, 6(1), 22-41.

Duran, M. (2015). Development process of guidance materials based on inquiry-based learning approaches and student opinions. International Online Journal of Educational Sciences, 7(3), 179-200.

Edelson, D.C. (2001). Design research: What we learn when we engage in design. Journal of the Learning Sciences, 11(1), 105-121.

Ercan, S., \& Şahin, F. (2015). The usage of engineering practices in science education: effects of design based science learning on students'academic achievement. Necatibey Faculty of Education Electronic Journal of Science and Mathematics Education, 9(1), 128-164.

Froyd, J. E., Wankat, P. C., \& Smith, K. A. (2012). Five major shifts in 100 years of engineering education. Proceedings of the IEEE, 100, 1344-1360.

Jollands, M., Jolly, L., \& Molyneaux, T. (2012). Project-based learning as a contributing factor to graduates' work readiness. European Journal of Engineering Education, 37, 143-154.

Kuzu, A., Çankaya, S., \& Misırlı, Z. A. (2011). Design-Based research and its implementation in the design and development of learning environments. Anadolu Journal of Educational Sciences International, 1(1), 19-35.

Kuzu, A., Cavkaytar, A., Çankaya, S., \& Öncül, N. (2013). Participants' views about mobile skill teaching software developed for parents of individuals with intellectual disability. Anadolu Journal of Educational Sciences International, 3(2), 1-21.

Lesh, R., \& Sriraman, B. (2005). Mathematics education as a design science. ZDM, 37(6), 490-505.

Levy, P., \& Petrulis, R. (2012). How do first-year university students experience inquiry and research, and what are the implications for the practice of inquiry-based learning?. Studies in Higher Education, 37(1), 85101.

Litzinger, T., Lattuca, L. R., Hadgraft, R., \& Newstetter, W. (2011). Engineering education and the development of expertise. Journal of Engineering Education, 100(1), 123-150.

McKenney, S., \& Reeves, T. C. (2013). Systematic review of design-based research progress: Is a little knowledge a dangerous thing?. Educational Researcher, 42(2), 97-100.

McNeill, N. J., Douglas, E. P., Koro-Ljungberg, M., Therriault, D. J., \& Krause, I. (2016). Undergraduate students' beliefs about engineering problem solving. Journal of Engineering Education, 105(4), 560-584.

Mills, J. E., \& Treagust, D. F. (2003). Engineering education - Is problem-based or project-based learning the answer?. Australasian Journal of Engineering Education, 3(2), 2-16. 
Özyurt Ö., \& Özyurt H. (2017a, December). Tasarım tabanlı araştırma ve yazılım mühendisliği eğitiminde uygulanabilirliği. Paper presented at I. Uluslararasi Türk Dünyasi Mühendislik ve Fen Bilimleri Kongresi, Antalya, Türkiye.

Özyurt Ö., \& Özyurt H. (2017b). Students' views about implementation of the database management systems course with inquiry-based method. İnönü Üniversitesi Ĕ̆itim Fakültesi Dergisi, 18(3), 49-60.

Palmer, S., \& Hall, W. (2011). An evaluation of a project-based learning initiative in engineering education. European Journal of Engineering Education, 36, 357-365.

Reeves, T. C. (2000). Enhancing the worth of instructional technology research through "design experiments" and other development research strategies. International perspectives on instructional technology research for the 21st century, New Orleans, LA, USA.

Wang, F., \& Hannafin, M.J. (2005). Design-based research and technology-enhanced learning environments. Educational Technology Research and Development, 53(4), 5-23.

Windschitl, M. (2003). Supporting the development of science inquiry skills with special classes of software. Educational Technology, Research and Development, 48(2), 81-95.

Yaman, F., Dönmez, O., Avcı, E., \& Yurdakul, I. K. (2016). İşitme engelli öğrencilerin okuma-yazma eğitiminde mobil uygulama kullanım. Eğitim ve Bilim, 41(188), 153-174.

Yıldırım, G. (2014). Tablet bilgisayarlara yönelik geliştirilen e-kitapların video ile zenginleştirilmesi süreci: bir tasarım tabanlı araştırma (Yayınlanmamış Doktora Tezi). Atatürk Üniversitesi, Erzurum, Türkiye.

Zhou, C. (2012). Integrating creativity training into problem and project based learning curriculum in engineering education. European Journal of Engineering Education, 37, 488-499. 